\title{
Analgesic Tolerance to High-Efficacy Agonists But Not to Morphine Is Diminished in Phosphorylation-Deficient S375A $\mu$-Opioid Receptor Knock-In Mice
}

\author{
Gisela Grecksch, ${ }^{1}$ Sascha Just, ${ }^{2}$ Claudia Pierstorff, ${ }^{1}$ Anne-Katja Imhof, ${ }^{2}$ Laura Glück, ${ }^{2}$ Christian Doll, ${ }^{2}$ Amelie Lupp, ${ }^{2}$ \\ Axel Becker, ${ }^{1}$ Thomas Koch, ${ }^{1}$ Ralf Stumm, ${ }^{2}$ Volker Höllt, ${ }^{1}$ and Stefan Schulz ${ }^{2}$ \\ ${ }^{1}$ Institute of Pharmacology and Toxicology, Faculty of Medicine, Otto-von-Guericke-University, D-39120 Magdeburg, Germany, and ${ }^{2}$ Institute of \\ Pharmacology and Toxicology, University Hospital, Friedrich Schiller University, D-07747 Jena, Germany
}

Morphine is one of the most potent analgesic drugs. However, the utility of morphine in the management of chronic pain is limited by its rapid development of tolerance. Morphine exerts all of its pharmacological effects via the $\mu$-opioid receptor. In many systems, tolerance is associated with phosphorylation and desensitization of G-protein-coupled receptors (GPCRs). In case of the $\mu$-opioid receptor, phosphorylation occurs in an agonist-selective manner. High-efficacy agonists such as [D-Ala ${ }^{2}$-MePhe ${ }^{4}$-Gly-ol] enkephalin (DAMGO), fentanyl, or etonitazene stimulate the phosphorylation of both C-terminal threonine 370 (T370) and serine 375 (S375). In contrast, morphine promotes the phosphorylation of S375 but fails to stimulate T370 phosphorylation. Here, we have assessed the contribution of S375 phosphorylation to the development of antinociceptive tolerance to high- and low-efficacy $\mu$ agonists in vivo. We show that $S 375$ phosphorylation of the $\mu$-opioid receptor occurs in intact mouse brain in a dose-dependent manner after administration of morphine, fentanyl, or etonitazene. In knock-in mice expressing the phosphorylation-deficient S375A mutant of the $\mu$-opioid receptor, morphine and fentanyl exhibited greater dose-dependent antinociceptive responses than in wild-type mice. However, acute and chronic tolerance to morphine was retained in S375A mutant mice. In contrast, antinociceptive tolerance after repeated subcutaneous application of etonitazene or repeated intracerebroventricular application of DAMGO was diminished. Thus, tolerance to $\mu$ agonists with different efficacies develops through distinct pathways. Whereas tolerance induced by DAMGO or etonitazene requires agonist-driven phosphorylation of $\mathrm{S} 375$, the development and maintenance of antinociceptive tolerance to morphine occurs independent of S375 phosphorylation.

\section{Introduction}

The development of analgesic tolerance to morphine occurs on continued use of the drug such that the amount of drug required to elicit pain relief must be increased to compensate for diminished responsiveness. However, the molecular mechanisms of morphine tolerance are far from being understood (Nestler, 1996; Koch et al., 2005; Bailey et al., 2006; Martini and Whistler, 2007). For many clinically used drugs, tolerance has been associated with phosphorylation, desensitization and downregulation of their G-protein-coupled receptors (GPCRs). However, morphine is unique in that it activates the $\mu$-opioid receptor without causing its rapid endocytosis (Keith et al., 1996; Schulz et al.,

Received May 9, 2011; revised July 18, 2011; accepted July 21, 2011.

Author contributions: G.G., S.J., A.-K.I., T.K., R.S., V.H., and S.S. designed research; G.G., S.J., C.P., A.-K.I., L.G., C.D., A.L., A.B., and T.K. performed research; R.S. and S.S. contributed unpublished reagents/analytic tools; G.G., S.J., C.P., A.-K.I., L.G., C.D., A.L., A.B., T.K., and S.S. analyzed data; G.G., A.-K.I., and S.S. wrote the paper.

This work was supported by the Deutsche Forschungsgemeinschaft (SCHU924/10-1), European Regional Development Fund, and the Doktor Robert Pfleger-Stiftung. We thank Heidrun Guder, Heike Stadler, and Gabriele Schulze for excellent technical assistance.

The authors declare no competing financial interests.

Correspondence should be addressed to Stefan Schulz, Institute of Pharmacology and Toxicology, University Hospital, Friedrich Schiller University, Drackendorfer Str. 1, D-07747 Jena, Germany. E-mail: Stefan.Schulz@ mti.uni-jena.de.

DOI:10.1523/JNEUROSCI.2304-11.2011

Copyright $\odot 2011$ the authors $\quad 0270-6474 / 11 / 3113890-07 \$ 15.00 / 0$
2004). We have recently generated phosphosite-specific antibodies for the C-terminal residues threonine 370 (T370) and serine 375 (S375), which enabled us to selectively detect either the T370phosphorylated or the S375-phosphorylated form of the $\mu$-opioid receptor (Doll et al., 2011). We found that full agonists such as [D-Ala ${ }^{2}-\mathrm{MePhe}^{4}$-Gly-ol] enkephalin (DAMGO), fentanyl, or etonitazene stimulate the phosphorylation of both T370 and S375 (Doll et al., 2011). S375 is the primary site of phosphorylation that contributes to desensitization, $\beta$-arrestin binding, and internalization of the $\mu$-opioid receptor (El Kouhen et al., 2001; Schulz et al., 2004; McPherson et al., 2010; Kelly, 2011). In contrast, morphine promoted the phosphorylation of S375 but failed to stimulate T370 phosphorylation (Schulz et al., 2004; Doll et al., 2011). Here, we show that the morphine-mediated S375 phosphorylation also occurs in vivo shortly after administration of the drug. To directly examine the contribution of S375 phosphorylation to the development of tolerance in vivo, we generated knock-in mice expressing the phosphorylation-deficient S375A mutant of the $\mu$-opioid receptor, and assessed opioidmediated responses in intact animals.

\section{Materials and Methods}

Animals. Knock-in mice expressing the S375A mutant of the $\mu$-opioid receptor $\left(\mathrm{MOR}^{\mathrm{S} 375 \mathrm{~A} / \mathrm{S} 375 \mathrm{~A}}\right)$ were generated at Ozgene. According to Mouse Genome Informatics (MGI, The Jackson Laboratory), the official 


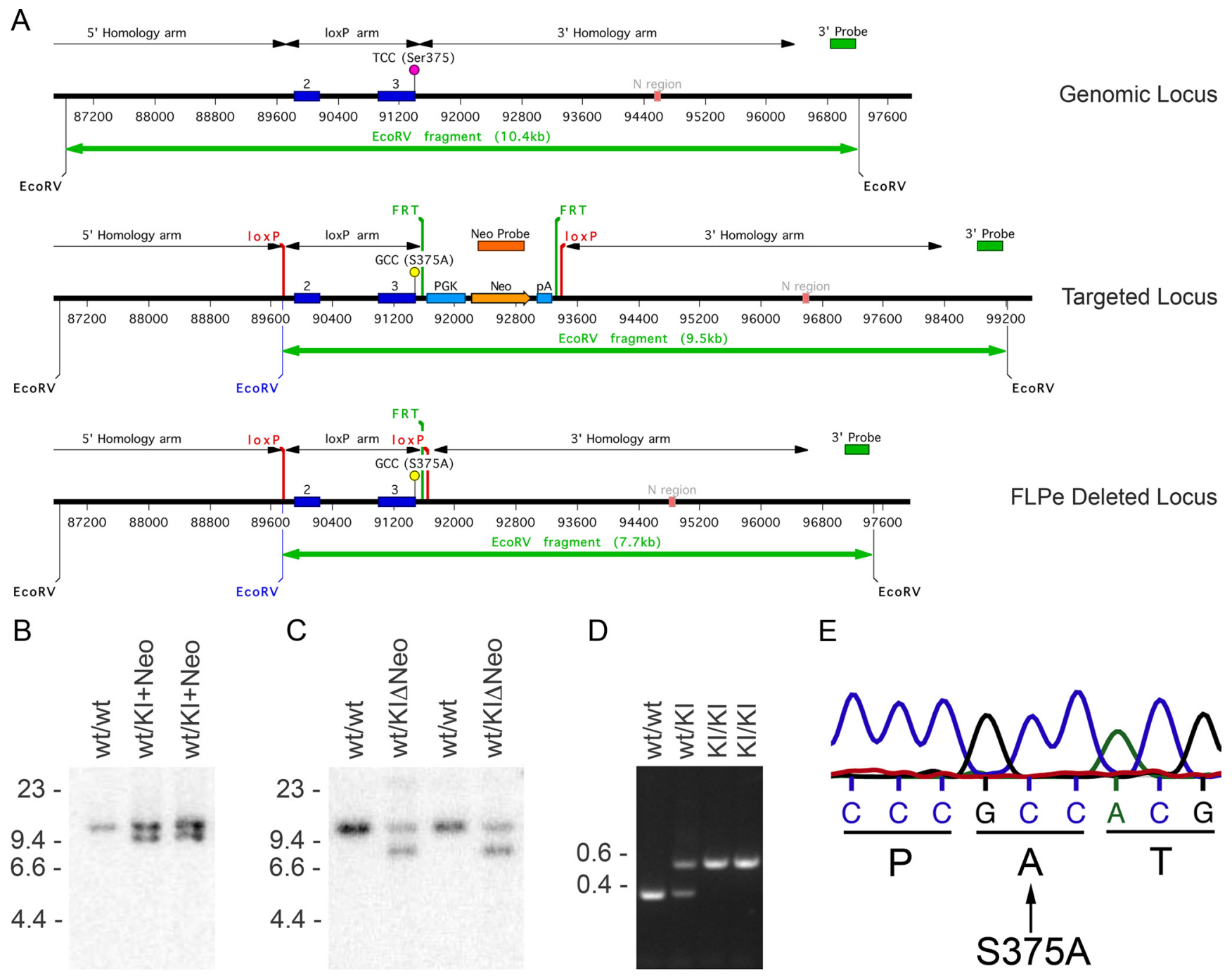

Figure 1. Generation of $M O R^{5375 A / 5375 A}$ mice. $A$, Schematic representation of targeting strategy. A genomic fragment containing the $\mu$-opioid receptor sequence, including exons 2 and 3 , was modified to contain the S375A mutation of the $\mu$-opioid receptor. A cassette containing resistance to neomycin (PKG-Neo) and flanked by FRT sites was inserted in the intron downstream of exon 3 for selection of ES cell clones. Exon 2 and 3 are also flanked with loxP sites. B, Detection of homologous recombination in ES cells by Southern blot using the $3^{\prime}$ probe. $C$, Verification of deletion of PKG-Neo cassette by Southern blot using the 3' probe after FlpE-mediated recombination. $\boldsymbol{D}$, Representative example of genotyping by PCR. $\boldsymbol{E}$, Bands in $\boldsymbol{D}$ were excised and sequenced to confirm presence of S375A mutation.

nomenclature for these mice is Oprm $1^{\text {tm1Shlz }}$ with accession number MGI:5000465. In this $\mu$-opioid receptor mutant, the coding sequence for serine 375 (TCC) has been replaced using PCR with the coding sequence of alanine (GCC) (Fig. 1). Bruce 4 C57BL/6J ES cells were used to generate $\mathrm{MOR}^{\mathrm{S} 375 \mathrm{~A} / \mathrm{S} 375 \mathrm{~A}}$ mice. Mice were genotyped by PCR of genomic tail DNA using the following primers: 5'-GGC TAA TAC AGT GGA TCG AAC TAA C-3' and 5'-TAA CTG TCT TGG CTA CAT TCC TTT C-3'. $\mathrm{MOR}^{\mathrm{S} 375 \mathrm{~A} / \mathrm{S} 375 \mathrm{~A}}$ and $\mathrm{MOR}^{+/+}$were generated by heterozygous breeding. In behavioral experiments, male mice aged 12-16 weeks between 25 and $30 \mathrm{~g}$ were used. Animals were housed in a $12 \mathrm{~h}$ light-dark cycle and had ad libitum access to food and water. All animal experiments were performed in accordance with the Thuringian state authorities and complied with EC regulations for the care and use of laboratory animals.

Drugs. Morphine- $\mathrm{HCl}$ and naloxone- $\mathrm{HCl}$ were purchased from Merck, and fentanyl-citrate from Rotexmedica. DAMGO was obtained from Bachem, and etonitazene- $\mathrm{HCl}$ was from Novartis. Drugs were dissolved in physiological saline and injected subcutaneously in a volume of $10 \mathrm{ml} / \mathrm{kg}$ or intracerebroventricularly in a volume of $2.5 \mu \mathrm{l}$.

Western blot and immunoprecipitation. Brains from $\mu$-opioid receptor-deficient mice $\left(\mathrm{MOR}^{-1-}\right.$ ) (provided by Dr. H. Loh, University of Minnesota, Minneapolis, $\mathrm{MN})$, wild-type mice $\left(\mathrm{MOR}^{+/+}\right)$, and $\mathrm{MOR}^{\mathrm{S} 375 \mathrm{~A} / \mathrm{S} 375 \mathrm{~A}}$ were quickly dissected after the indicated treatment.
The cerebellum, which is devoid of $\mu$-opioid receptors, was removed, and the remaining brain samples were immediately frozen in liquid nitrogen. In all experiments, entire brains except cerebellum were used. Samples were then transferred to ice-cold detergent buffer $(50 \mathrm{~mm}$ Tris$\mathrm{HCl}, \mathrm{pH}$ 7.4, 150 mм NaCl, 5 mм EDTA, 10 mм NaF, 10 mм disodium pyrophosphate, $1 \%$ Nonidet P- $40,0.5 \%$ sodium deoxycholate, $0.1 \%$ SDS containing protease and phosphatase inhibitors), homogenized, and centrifuged at $16,000 \times g$ for $30 \mathrm{~min}$ at $4^{\circ} \mathrm{C}$. The supernatant was then immunoprecipitated with the phosphorylation-independent rabbit monoclonal anti-MOR antibody $\{\mathrm{UMB}-3\}$ bound to protein A-agarose beads for $2 \mathrm{~h}$ at $4^{\circ} \mathrm{C}$ (Lupp et al., 2011). Proteins were eluted from the beads with SDS-sample buffer for $20 \mathrm{~min}$ at $40^{\circ} \mathrm{C}$. Samples were resolved on $8 \%$ SDS-polyacrylamide gels, and after electroblotting, membranes were incubated with guinea pig polyclonal anti-pS375 antibody $\{\mathrm{GP} 2\}$ at a concentration of $0.1 \mu \mathrm{g} / \mathrm{ml}$ followed by detection using an enhanced chemiluminescence detection system (GE Healthcare). Blots were subsequently stripped and reprobed with phosphorylation independent guinea pig polyclonal anti-MOR antibody $\{\mathrm{GP} 6\}$ at a concentration of $0.1 \mu \mathrm{g} / \mathrm{ml}$ to confirm equal loading of the gels. The rabbit monoclonal antibody UMB-3 was obtained from Epitomics. The phosphorylationindependent antibodies $\{\mathrm{UMB}-3\}$ and $\{\mathrm{GP} 6\}$ were generated against the $\mathrm{C}$-terminal tail of the mouse $\mu$-opioid receptor. The identity of the pep- 
tide used for immunizations of the rabbits was LENLEAETAPLP, which corresponds to residues $386-398$ of the mouse $\mu$-opioid receptor. These antibodies have been extensively characterized previously (Schulz et al., 2004; Doll et al., 2011a,b; Lupp et al., 2011). The phosphosite-specific antibody for the S375-phosphorylated form of the $\mu$-opioid receptor $\{\mathrm{GP} 2\}$ was generated against the following sequence that contained a phosphorylated serine residue: REHP(pS)TANTV. This sequence corresponds to amino acids $371-380$ of the mouse $\mu$-opioid receptor. The anti-pS375 guinea pig polyclonal anti-MOR antibody $\{\mathrm{GP} 2\}$ has been generated and characterized in an identical manner to that previously described for the anti-pS375 rabbit polyclonal anti-MOR antibody $\{2493\}$ (Doll et al., 2011b). When indicated, lysates were sequentially incubated with WGA (wheat germ lectin agarose) beads to enrich glycoproteins after UMB-3 immunoprecipitation. These samples were then probed with an anti-transferrin receptor (TFR) antibody (Zymed) to confirm that equal amounts of lysate of each sample were used for UMB-3 immunoprecipitation.

Immunohistochemistry. Animals were killed under ether anesthesia, and brains and spinal cords were removed, fixed in 10\% buffered formaldehyde, and embedded in paraffin for immunohistochemistry. Fivemicrometer sections from brain and spinal cord were cut and floated onto positively charged slides. Immunostaining was performed by an indirect peroxidase labeling method as described previously (Lupp et al., 2011). Briefly, sections were dewaxed, microwaved in $10 \mathrm{~mm}$ citric acid, $\mathrm{pH}$ 6.0, for $16 \mathrm{~min}$ at $600 \mathrm{~W}$, and then incubated with the rabbit monoclonal anti-MOR antibody UMB-3 (dilution 1:10) overnight at $4^{\circ} \mathrm{C}$. Detection of the primary antibody was performed using a biotinylated anti-rabbit IgG followed by incubation with peroxidase-conjugated avidin (Vector ABC "Elite" kit, Vector). Binding of the primary antibody was visualized using 3-amino-9-ethylcarbazole (AEC) in acetate buffer (BioGenex).

Analgesia-hot plate test. Basal pain responses were determined at hot plate temperatures of $50^{\circ} \mathrm{C}, 52^{\circ} \mathrm{C}, 54^{\circ} \mathrm{C}$, and $56^{\circ} \mathrm{C}$ on consecutive test days. In each antinociception assay, nociceptive latencies were assessed as the response time to the hot plate $\left(56^{\circ} \mathrm{C}\right)$. The "response" was defined by the animal either licking or flicking his hindpaws. To avoid tissue damage, an artificial maximum time for exposure was imposed, which prevented the animal from contact with the plate for $>30 \mathrm{~s}$. Data are reported as the percentage maximum possible effect (\% MPE), which was determined by accounting for each individual's basal response as well as the imposed maximum cutoff time using the following calculation: $100 \times[($ drug response time - basal response time $) /(30 \mathrm{~s}-$ basal response time $)]=\%$ MPE. In morphine dose-response studies, withdrawal latencies were measured $30 \mathrm{~min}$ after a first dose of morphine (1 $\mathrm{mg} / \mathrm{kg}$, s.c.); at this time point, animals were injected with morphine (4 $\mathrm{mg} / \mathrm{kg}$, s.c.) for a cumulative dose of $5 \mathrm{mg} / \mathrm{kg}$. Antinociception was again assessed after $30 \mathrm{~min}$, and mice were again injected with morphine (5 $\mathrm{mg} / \mathrm{kg}$, s.c.) to yield a final cumulative dose of $10 \mathrm{mg} / \mathrm{kg}$. After $30 \mathrm{~min}$, antinociception was assessed once more. In fentanyl dose-response studies, withdrawal latencies were measured $30 \mathrm{~min}$ after a first dose of fentanyl $(0.05 \mathrm{mg} / \mathrm{kg}$, s.c. $)$; at this time point, animals were injected with fentanyl $(0.05 \mathrm{mg} / \mathrm{kg}$, s.c. $)$ for a cumulative dose of $0.1 \mathrm{mg} / \mathrm{kg}$. Antinociception was again assessed after $30 \mathrm{~min}$, and mice were again injected with fentanyl $(0.2 \mathrm{mg} / \mathrm{kg}$, s.c. $)$ to yield a final cumulative dose of 0.3 $\mathrm{mg} / \mathrm{kg}$. After $30 \mathrm{~min}$, antinociception was assessed once more. Acute antinociceptive tolerance was induced by treating $\mathrm{MOR}^{\mathrm{S} 375 \mathrm{~A} / \mathrm{S} 375 \mathrm{~A}}$ mice and their wild-type littermates $\left(\mathrm{MOR}^{+/+}\right)$with saline or morphine (100 $\mathrm{mg} / \mathrm{kg}$, s.c.). After $12 \mathrm{~h}$, all mice were treated with a challenge dose of morphine $(10 \mathrm{mg} / \mathrm{kg}$, s.c.), and hot plate latencies (Ugo Basile) were recorded. Twenty-four hours after morphine treatment, both genotypes had returned to their basal nociceptive latencies.

Analgesia-electrical tail root stimulation test. A 0.1-mm-thick stainless steel wire was subcutaneously drawn through the root of the tail under pentobarbital anesthesia $(40 \mathrm{mg} / \mathrm{kg}$, i.p.) $3 \mathrm{~d}$ before the start of the experiments. The second electrode was the plate of the restraining tube (diameter $=3 \mathrm{~cm}$, length $=8 \mathrm{~cm}$ ). The plate of the tube and the subcutaneously implanted electrode were connected with a stimulating current apparatus (TuR RS12). The current intensity (rectangular pulses, $50 \mathrm{~Hz}$, $50 \mathrm{~ms}$ impulse width) was continuously increased until the animal vo- calized. The maximum stimulation was set at $300 \mathrm{~mA}$ (impulse peak). After vocalization or after reaching the impulse peak, the current was immediately switched off. On test days, pain thresholds were determined as mean of three electrical stimulations performed in 1 min intervals before and $30 \mathrm{~min}$ after drug application. Data are reported as the maximum possible effect (\% MPE), which was determined by accounting for each individual's basal response as well as the imposed maximum stimulation using the following calculation: $100 \times[$ (drug response current basal response current $) /(300 \mathrm{~mA}-$ basal response current $)]=\% \mathrm{MPE}$. Chronic antinociceptive tolerance was induced by daily subcutaneous treatment with $30 \mathrm{mg} / \mathrm{kg}$ morphine or $30 \mu \mathrm{g} / \mathrm{kg}$ etonitazene for 12 consecutive days. Antinociceptive activity was evaluated on days 1, 3, 5, 8, 10, and $12,30 \mathrm{~min}$ after application of challenge doses of $15 \mathrm{mg} / \mathrm{kg}$ morphine or $15 \mu \mathrm{g} / \mathrm{kg}$ etonitazene. The rest of the daily dose was injected after the behavioral test. Chronic antinociceptive tolerance was induced by daily intracerebroventricular application of $20 \mathrm{nmol}$ of morphine, $10 \mathrm{nmol}$ of etonitazene, or $10 \mathrm{nmol}$ of DAMGO in a volume of $2.5 \mu \mathrm{l}$. One week before the experiments, microcannulas for intracerebroventricular application of the substances were implanted under pentobarbital anesthesia into the right lateral ventricle [coordinates: $\mathrm{AP}=-0.2 \mathrm{~mm}$, lateral $=0.2 \mathrm{~mm}$ (relative to bregma), vertical $=2.5 \mathrm{~mm}]$. Microcannulas were fixed with a socket of acrylic dental cement. Antinociceptive activity was evaluated on days $1,4,8,11$, and 16, $30 \mathrm{~min}$ after drug treatment.

\section{Results}

\section{$\boldsymbol{\mu}$-Opioid receptors are upregulated during chronic morphine treatment}

To facilitate detection of endogenous $\mu$-opioid receptors in mouse brain, we have extensively characterized the rabbit monoclonal anti-MOR antibody $\{$ UMB-3 $\}$ (Doll et al., 2011b; Lupp et al., 2011). When crude brain homogenates from $\mathrm{MOR}^{+/+}$mice were immunoprecipitated with UMB-3, the guinea pig antiMOR antibody $\{$ GP6 $\}$ detected a broad band migrating at $M_{\mathrm{r}}$ $70,000-80,000$ in the subsequent immunoblot (Fig. $2 A$ ). In contrast, no such band was detectable in brain homogenates prepared from $\mathrm{MOR}^{-1-}$ mice under otherwise identical conditions (Fig. 2 A). When $\mathrm{MOR}^{+/+}$mice were treated for $9 \mathrm{~d}$ with escalating doses of morphine, $\mu$-opioid receptor expression was strongly upregulated as compared to saline-treated animals (Fig. $2 B, C)$. In contrast, such an upregulation was not seen in animals that had been treated for $9 \mathrm{~d}$ with escalating doses of etonitazene (Fig. $2 B, C$ ).

\section{Dose-dependent S375 phosphorylation in vivo}

To facilitate detection of S375-phosphorylated $\mu$-opioid receptors in UMB-3 immunoprecipitates from mouse brain, we generated a guinea pig polyclonal anti-pS375 antibody $\{\mathrm{GP} 2\}$. When brain homogenates from $\mathrm{MOR}^{+/+}$mice were immunoprecipitated with UMB-3, the guinea pig anti-pS375 antibody $\{\mathrm{GP} 2\}$ detected a broad band migrating at $M_{\mathrm{r}} 70,000-80,000$ only in morphine- or etonitazene-treated but not in saline-treated animals (Fig. 3A). In contrast, no such band was detectable in brain homogenates prepared from $\mathrm{MOR}^{\mathrm{S} 375 \mathrm{~A} / \mathrm{S} 375 \mathrm{~A}}$ mice after identical drug treatment (Fig. 3A). These findings clearly show that S375 phosphorylation of the $\mu$-opioid receptor occurs also in mouse brain after administration of morphine. MOR ${ }^{\mathrm{S} 375 \mathrm{~A} / \mathrm{S} 375 \mathrm{~A}}$ mice exhibited similar densities of $\mu$-opioid receptors with a similar cellular and subcellular distribution in the spinal cord, and all other investigated brain regions, including dorsal root ganglia, thalamus, striatum, and cortex, were devoid of any detectable anatomical abnormality compared to $\mathrm{MOR}^{+/+}$mice (Fig. $3 A, B)$. When $\mathrm{MOR}^{+/+}$mice were treated with increasing doses of morphine (2-100 mg/kg, s.c.) or fentanyl (0.02-1 mg/kg, s.c.), a dose-dependent increase in S375 phosphorylation was observed (Fig. 4A). S375 phosphorylation of the $\mu$-opioid receptor was 


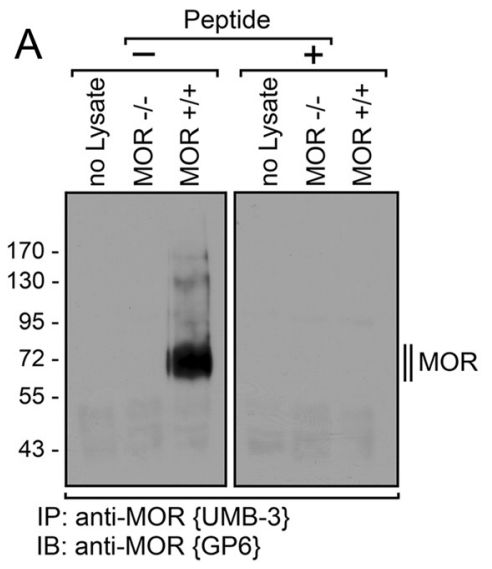

B

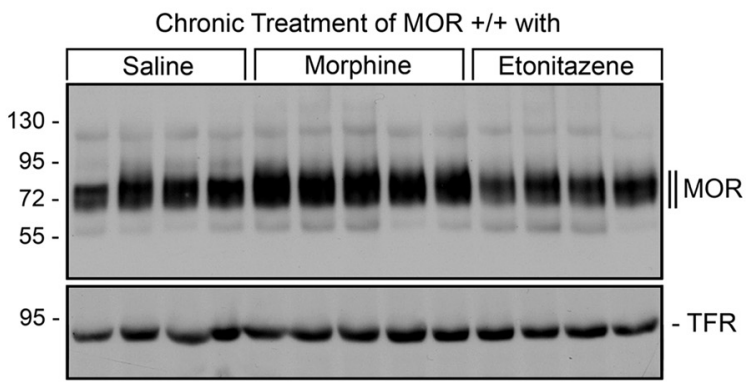

IP: anti-MOR \{UMB-3\}

IB: anti-MOR $\{$ GP6 $\}$
C

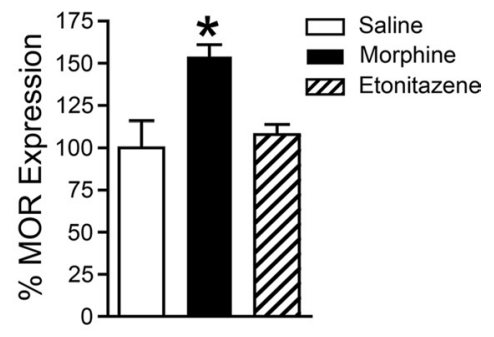

Figure 2. Upregulation of $\mu$-opioid receptor expression during chronic morphine treatment. $A$, Immunoprecipitation of $\mu$-opioid receptors from cell-lysate free samples (no lysate) and brain homogenates prepared from MOR ${ }^{+/+}$or MOR ${ }^{-1-}$ mice. Homogenates were prepared from entire brain after removal of the cerebellum. $\mu$-0pioid receptors were immunoprecipitated with UMB-3 bound to protein A agarose beads. Samples were separated on 8\% SDS-polyacrylamide gels and blotted. Blots were incubated with guinea pig anti-MOR antiserum \{GP6\}. Incubations were performed in the absence $(-)$ or presence $(+)$ of the peptide antigen. Note that UMB-3 selectively detects $\mu$-opioid receptors and does not cross-react with other proteins present in tissue extracts prepared from MOR ${ }^{-/-}$mice. B, MOR ${ }^{+/+}$mice were treated for $9 \mathrm{~d}$ with saline (lanes 1-4), escalating doses of morphine $(10-90 \mathrm{mg} / \mathrm{kg}$, s.c.) (lanes 5-9), or escalating doses of etonitazene $(10-90 \mu \mathrm{g} / \mathrm{kg}$, s.c.) (lanes $10-13)$. One hour after the last injection, brains were dissected. Homogenates were prepared from entire brain after removal of the cerebellum. $\mu$-0pioid receptors were immunoprecipitated with UMB-3 and immunoblotted with guinea pig anti-MOR antiserum \{GP6\} (top). After UMB-3 immunoprecipitation, lysates were subsequently incubated with wheat germ lectin agarose beads to enrich glycoproteins. These samples were then probed with an anti-TFR antibody to confirm that equal amounts of lysate were used for UMB-3 immunoprecipitation (bottom). Each lane represents one animal. C, Blots were quantified by densitometry and expressed as percentage of $\mu$-opioid receptor expression in saline-treated animals. Data correspond to the mean \pm SEM. Results were analyzed by one-way ANOVA followed by the Bonferroni post hoc test ( ${ }^{*} p<0.05$ ). Note that $\mu$-opioid receptor expression is upregulated during chronic morphine but not during chronic etonitazene. The positions of the molecular mass markers are indicated on the left (in kilodaltons).

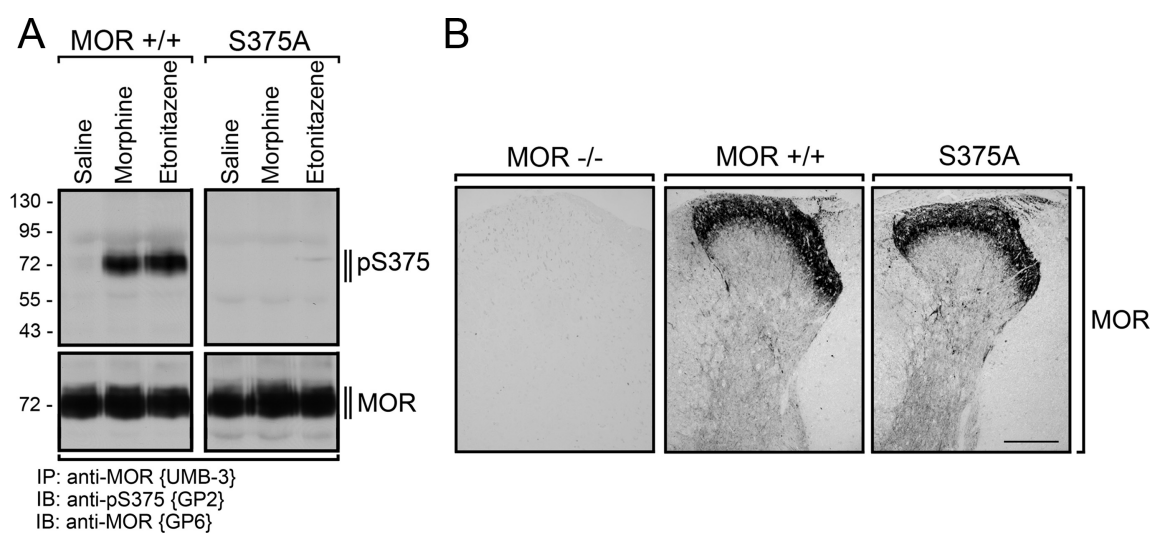

Figure 3. Detection of agonist-induced $S 375$ phosphorylation in vivo. $A, M O R^{+/+}$and $M O R^{S 375 A / S 375 A}$ mice were treated with saline, morphine ( $30 \mathrm{mg} / \mathrm{kg}$, s.c.), or etonitazene (30 $\mu \mathrm{g} / \mathrm{kg}$, s.c.). After $30 \mathrm{~min}$, brains were dissected. Homogenates were prepared from entire brain after removal of the cerebellum. $\mu$-0pioid receptors were immunoprecipitated with UMB-3 and immunoblotted with guinea pig anti-pS375 antibody \{GP2\} (top). Blots were stripped and reprobed with the phosphorylationindependent guinea pig anti-MOR antibody $\{G P 6\}$ to confirm equal loading of the gel (bottom). Note that both morphine and etonitazene stimulated S375 phosphorylation of the $\mu$-opioid receptor. No such band was detectable in saline-treated MOR ${ }^{+/+}$ or in $M O R^{5375 A / 5375 A}$ mice. The positions of the molecular mass markers are indicated on the left (in kilodaltons). $\boldsymbol{B}$, Spinal cords from MOR ${ }^{-1-}, M O R^{+/+}$, and MOR ${ }^{5375 A / 5375 A}$ mice were dissected, fixed in formalin, and embedded in paraffin. Sections were dewaxed, microwaved in citric acid, and incubated with anti-MOR antibody \{UMB-3). Specimens were then sequentially treated with biotinylated anti-rabbit lgG and peroxidase-conjugated avidin and developed in AEC. Note that $\mu$-opioid receptors have similar density and distribution in $M O R^{+/+}$and in $\mathrm{MOR}^{5375 A / 5375 A}$ mice. Scale bar: $\boldsymbol{B}, 200 \mu \mathrm{m}$.

completely blocked by coadministration of naloxone (Fig. $4 A$ ). The level of S375 phosphorylation correlated well to the dosedependent antinociceptive responses evoked by a single injection of morphine or fentanyl in $\mathrm{MOR}^{+/+}$mice, suggesting that $\mathrm{S} 375$ phosphorylation occurs at pharmacologically relevant doses (Fig. $4 A, B$ ).

\section{Enhanced acute antinociceptive responses in} $\mathrm{MOR}^{\mathrm{S375A} / \mathrm{S} 375 \mathrm{~A}}$ mice

We then compared acute antinociceptive responses in $\mathrm{MOR}^{\mathrm{S} 375 \mathrm{~A} /}$ S375A and $\mathrm{MOR}^{+/+}$mice. Initial experiments revealed that
$\mathrm{MOR}^{\mathrm{S} 375 \mathrm{~A} / \mathrm{S} 375 \mathrm{~A}}$ and $\mathrm{MOR}^{+/+}$exhibited similar basal pain responses as determined using the hot plate test (data not shown). Next, opioid-induced antinociception was evaluated after administration of increasing doses of morphine (1-10 mg/kg, s.c.) or fentanyl (0.05-0.3 $\mathrm{mg} / \mathrm{kg}$, s.c.). Under these conditions, it became apparent that knock-in mice expressing the phosphorylation-deficient S375A mutant of the $\mu$-opioid receptor exhibited greater dose-dependent antinociceptive responses to morphine and fentanyl than their wild-type littermates (Fig. 4B). These results suggest that S375 phosphorylation is required for acute desensitization of the $\mu$-opioid receptor after exposure to both morphine and fentanyl.

\section{Acute tolerance to morphine is retained} in MOR ${ }^{\text {S375A/S375A }}$ mice

We then examined whether $\mathrm{MOR}^{\mathrm{S} 375 \mathrm{~A} /}$ 5375A mice would develop acute tolerance to morphine. To examine this, we injected a "high" dose of morphine $(100 \mathrm{mg} / \mathrm{kg}$, s.c.) and evaluated the antinociceptive effect of a "normal" dose of morphine ( $10 \mathrm{mg} / \mathrm{kg}$, s.c.) $12 \mathrm{~h}$ later. When a "high" dose of morphine was injected, we observed a rapid and transient $\mathrm{S} 375$ phosphorylation (Fig. 5A). As depicted in Figure $5 B$, morphine pretreatment resulted in a similar robust acute tolerance in both $\mathrm{MOR}^{\mathrm{S375A/S375A} \text { and }}$ $\mathrm{MOR}^{+/+}$mice. When comparing the results from Figure 5, A and $B$, it becomes apparent that S375 phosphorylation declines within $8 \mathrm{~h}$, whereas acute tolerance is still detectable $12 \mathrm{~h}$ after morphine application. 
Chronic tolerance to high-efficacy agonists but not to morphine is diminished in MOR S375A/S375A $^{\text {mice }}$ Analgesic tolerance typically develops over the course of repeated administration of opioids during the treatment of chronic pain. Thus, we evaluated the development of tolerance after daily subcutaneous administration of equieffective doses of morphine $(30 \mathrm{mg} / \mathrm{kg}$ ) or etonitazene $(30 \mu \mathrm{g} / \mathrm{kg})$ over $12 \mathrm{~d}$. Unlike fentanyl, etonitazene has a similar duration of action as morphine when applied subcutaneously at equieffective doses. Consequently, etonitazene was used instead of fentanyl for chronic experiments. Given that a decrease in hot plate latency is known to occur with repeated testing, opioid-induced antinociception was evaluated by the electrical tail root stimulation test in addition to the hot plate test (Grecksch et al., 2006). Under these conditions, analgesic tolerance to morphine developed rapidly in both $\mathrm{MOR}^{\mathrm{S} 375 \mathrm{~A} /}$ S375A and $\mathrm{MOR}^{+/+}$mice (Fig. 6A). Similar to that previously observed in rats (Grecksch et al., 2006), tolerance to etonitazene developed at a slower time course in $\mathrm{MOR}^{+/+}$mice than tolerance to morphine. Nevertheless, the development of antinociceptive tolerance to etonitazene in $\mathrm{MOR}^{\mathrm{S} 375 \mathrm{~A} / \mathrm{S} 375 \mathrm{~A}}$ mice was significantly reduced (Fig. 6B). DAMGO is a prototypical highly selective agonist often used to study $\mu$-opioid receptor regulation. We therefore evaluated the development of tolerance after daily intracerebroventricular administration of morphine (20 nmol), etonitazene (10 nmol), or DAMGO (10 nmol) over $16 \mathrm{~d}$. Again, analgesic tolerance to morphine developed rapidly in both $\mathrm{MOR}^{\mathrm{S} 375 \mathrm{~A} / \mathrm{S} 375 \mathrm{~A}}$ and $\mathrm{MOR}^{+/+}$mice (Fig. 7A), whereas the development of antinociceptive tolerance to intracerebroventricular administration of etonitazene in $\mathrm{MOR}^{\mathrm{S375A} / \mathrm{S} 375 \mathrm{~A}}$ mice was significantly reduced (Fig. 7B). Robust analgesic tolerance also developed in $\mathrm{MOR}^{+/+}$mice after repeated intracerebroventricular administration of DAMGO (Fig. 7C). In contrast, MOR ${ }^{\mathrm{S} 375 \mathrm{~A} /}$ S375A mice did not develop tolerance to the antinociceptive effects of DAMGO during the $16 \mathrm{~d}$ treatment period. Similar results were obtained with both hot plate and electrical tail root stimulation test. These findings suggest that tolerance induced by DAMGO or etonitazene requires agonist-driven phosphorylation of S375, whereas the development of antinociceptive tolerance to morphine occurs independent of S375 phosphorylation.

\section{Discussion}

For many clinically used drugs such as $\beta_{2}$ agonists, GnRH analogs, or oxytocin, tolerance has been associated with phosphorylation, internalization, and ultimately downregulation of their targeted GPCRs. Morphine is unique in that it is a poor inducer of $\mu$-opioid receptor internalization, but a potent inducer of cellular tolerance in vivo. In the present study, we clearly show that chronic morphine produces a significant upregulation rather than downregulation of $\mu$-opioid receptors in vivo under conditions that induce profound cellular tolerance. This is in contrast to the majority of previous binding studies, which detected

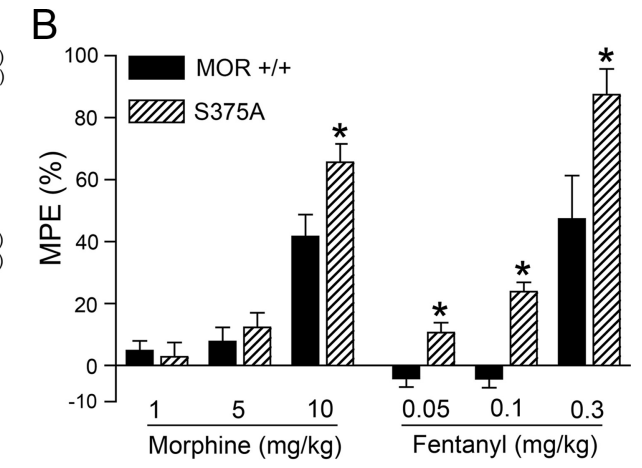



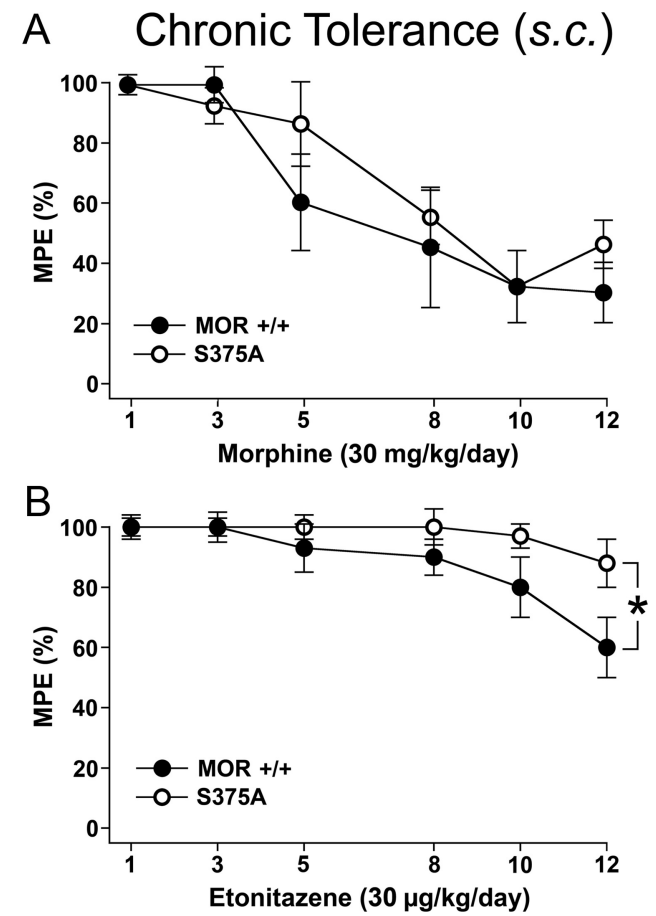

Figure 6. Chronic tolerance to subcutaneous etonitazene but not to morphine is diminished in $M O R^{5375 A / 5375 A}$ mice. $\boldsymbol{A}, \boldsymbol{B}$, chronic tolerance in $M O R^{+/+}$and $M O R^{5375 A / 5375 A}$ mice was determined after daily subcutaneous injection of morphine $(30 \mathrm{mg} / \mathrm{kg}$ ) or etonitazene (30 $\mu \mathrm{g} / \mathrm{kg}$ ) for $12 \mathrm{~d}$. On days $1,3,5,8,10$, and 12 , antinociceptive response was determined 30 min after application challenge doses of $15 \mathrm{mg} / \mathrm{kg}$ morphine or $15 \mu \mathrm{g} / \mathrm{kg}$ etonitazene using electrical tail root stimulation. The rest of the daily dose was injected after the behavioral test. The current intensity was continuously increased until the animal vocalized. To avoid tissue damage, a maximum stimulation of $300 \mathrm{~mA}$ was imposed. After vocalization or after reaching the impulse peak, the current was immediately switched off. On test days, pain thresholds were determined as mean of three electrical stimulations performed in intervals of exactly 1 min before and $30 \mathrm{~min}$ after drug application. Data are reported as \% MPE. Data are presented as the means \pm SEM from MOR ${ }^{+1+}$ mice (morphine: $n=12$, etonitazene: $n=10$ ) and MOR ${ }^{5375 A / 5375 A}$ mice (morphine: $n=16$, etonitazene: $n=16$ ). Results were analyzed by two-way ANOVA with repeated measures (time $X$ treatment: $p<0.01$ ) followed by the Bonferroni post hoc test $(A$, status effect by morphine treatment: not significant; $\boldsymbol{B}$, status effect by etonitazene treatment: $\left.{ }^{*} p<0.011\right)$.

$\mu$-opioid receptors accumulate at the cell surface. Thus, changes in total $\mu$-opioid receptor protein may be detectable only by immunoprecipitation and not by receptor binding.

Recently, we have used novel phosphosite-specific antibodies in combination with siRNA knock down screening to identify the G-protein-coupled receptor kinases (GRKs) involved in agonistdependent phosphorylation of the $\mu$-opioid receptor (C. Doll, F. Poll, and S. Schulz, unpublished work). We found that the morphine-activated $\mu$-opioid receptor acquires a conformation that is an efficient substrate for phosphorylation by GRK5 but a poor substrate for phosphorylation by GRK2/3 (C. Doll, F. Poll, and S. Schulz, unpublished work). GRK5 phosphorylates $\mu$-opioid receptors selectively on S375, which is not sufficient to facilitate receptor sequestration. Conversely, $\mu$-opioid receptors activated by high-efficacy agonists acquire a conformation that is an efficient substrate for phosphorylation by GRK2/3 but a poor substrate for phosphorylation by GRK5 (C. Doll, F. Poll, and S. Schulz, unpublished work). GRK2/3 phosphorylate $\mu$-opioid receptors at a number of C-terminal phosphate acceptor sites, including T370 and S375, which in turn facilitates a robust receptor endocytosis (C. Doll, F. Poll, and S. Schulz, unpublished work). We have also shown that $\mu$-opioid receptor phosphorylation is a hierarchical process (Doll et al., 2011). Upon exposure to

\section{A Chronic Tolerance (i.c.v.)}
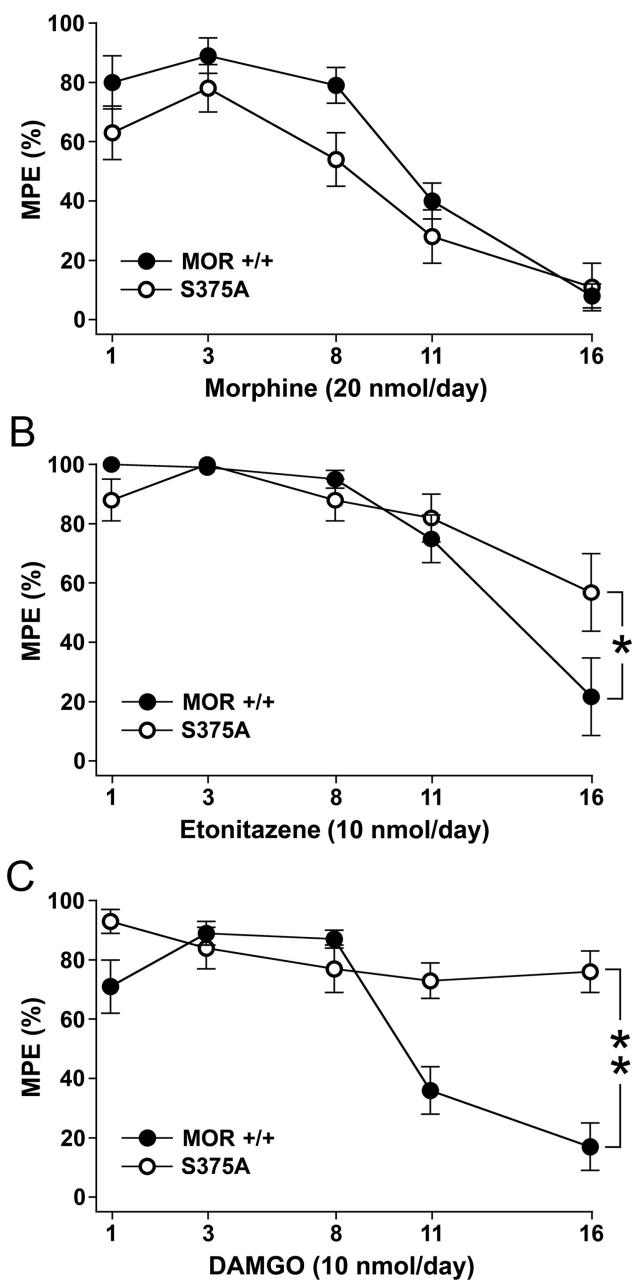

Figure 7. Chronic tolerance to high-efficacy agonists but not to morphine is diminished in MOR ${ }^{\text {S375A/S375A }}$ mice. $A-C$, Chronic tolerance in MOR ${ }^{+/+}$and MOR ${ }^{\text {S375A/S375A }}$ mice was determined after daily intracerebroventricular application of $20 \mathrm{nmol}$ of morphine, $10 \mathrm{nmol}$ of etonitazene, or $10 \mathrm{nmol}$ of DAMG0 in a volume of $2.5 \mu \mathrm{l}$ for $16 \mathrm{~d}$. On days $1,3,8,11$, and 16, antinociceptive response was determined $30 \mathrm{~min}$ after drug application using electrical tail root stimulation. The current intensity was continuously increased until the animal vocalized. To avoid tissue damage, a maximum stimulation of $300 \mathrm{~mA}$ was imposed. After vocalization or after reaching the impulse peak, the current was immediately switched off. On test days, pain thresholds were determined as mean of three electrical stimulations performed in intervals of exactly $1 \mathrm{~min}$ before and $30 \mathrm{~min}$ after drug application. Data are reported as \% MPE. Data are presented as the means \pm SEM from MOR ${ }^{+/+}$mice (morphine: $n=12$, entonitazene: $n=12$, DAMGO: $n=12$ ) and MOR ${ }^{S 375 A / S 375 A}$ mice (morphine: $n=13$, entonitazene: $n=13$, DAMG0: $n=14$ ). Results were analyzed by two-way ANOVA with repeated measures (time $\times$ treatment: $p<0.001$; treatment $\times$ time: $p<0.02$; genotype $\times$ treatment: $p<0.003$ ) followed by the Bonferroni post hoc test (morphine $\times$ DAMG0 and etonitazene, $p<0.001 ; \boldsymbol{A}$, status effect by morphine treatment: not significant; $\boldsymbol{B}$, status effect by etonitazene treatment: ${ }^{*} p<$ $0.04 ;$, status effect by DAMG0 treatment, ${ }^{* *} p<0.001$ ).

DAMGO, S375 is phosphorylated more rapidly than T370. T370 phosphorylation and internalization is strongly reduced in the S375A mutant, suggesting that S375 is the primary site of phosphorylation and that phosphorylation of T370 is in part dependent on the prior phosphorylation of S375 (Schulz et al., 2004; Doll et al., 2011).

Here, we clearly show that S375 phosphorylation of the $\mu$-opioid receptor occurs in vivo in mouse brain shortly after opioid administration. S375 phosphorylation was dose dependent and occurred at pharmacologically relevant doses. We hy- 
pothesized that $S 375$ phosphorylation would be an initial event in opioid-mediated $\mu$-opioid receptor desensitization. Thus, to directly assess the contribution of S375 phosphorylation to the development of morphine antinociceptive tolerance, we generated a novel knock-in mouse expressing the S375A mutant of the $\mu$-opioid receptor. In fact, S375A mutant mice exhibit greater dose-dependent antinociceptive responses to morphine and fentanyl than their wild-type littermates, supporting the idea that S375 phosphorylation is involved in acute $\mu$-opioid receptor desensitization. In contrast to our initial hypothesis, however, we found that acute and chronic tolerance to morphine was retained in S375A mutant mice. Nevertheless, we also found that antinociceptive tolerance after repeated subcutaneous application of etonitazene or repeated intracerebroventricular application of DAMGO or etonitazene was diminished. The phenotype we observed in S375A knock-in mice resembles closely that reported for GRK3 knock-out mice, in which the development of tolerance to the high-efficacy agonist fentanyl is strongly reduced, whereas acute and chronic tolerance to morphine is retained (Terman et al., 2004). Similar, intracerebroventricular injection of a smallmolecule GRK2 inhibitor reversed tolerance to DAMGO but not to morphine (Hull et al., 2010). Conversely, mice lacking $\beta$-arrestin-2 show diminished antinociceptive tolerance to morphine only but not to high-efficacy agonists such as fentanyl or methadone (Bohn et al., 1999, 2000; Dang et al., 2011; Raehal and Bohn, 2011). Moreover, inhibition of PKC reversed tolerance to morphine but not to DAMGO (Bailey et al., 2006, 2009; Hull et al., 2010).

Together, tolerance to $\mu$ agonists with different efficacy develops through distinct pathways. Tolerance induced by highefficacy agonists such as DAMGO, fentanyl, or etonitazene requires prototypical GRK2/3-mediated phosphorylation of S375. In contrast, the development and maintenance of antinociceptive tolerance to morphine occurs independent of S375 phosphorylation.

\section{References}

Bailey CP, Smith FL, Kelly E, Dewey WL, Henderson G (2006) How important is protein kinase $\mathrm{C}$ in mu-opioid receptor desensitization and morphine tolerance? Trends Pharmacol Sci 27:558-565.

Bailey CP, Oldfield S, Llorente J, Caunt CJ, Teschemacher AG, Roberts L, McArdle CA, Smith FL, Dewey WL, Kelly E, Henderson G (2009) Involvement of PKC alpha and G-protein-coupled receptor kinase 2 in agonist-selective desensitization of mu-opioid receptors in mature brain neurons. Br J Pharmacol 158:157-164.

Bohn LM, Lefkowitz RJ, Gainetdinov RR, Peppel K, Caron MG, Lin FT (1999) Enhanced morphine analgesia in mice lacking beta-arrestin 2. Science 286:2495-2498.

Bohn LM, Gainetdinov RR, Lin FT, Lefkowitz RJ, Caron MG (2000) Mu- opioid receptor desensitization by beta-arrestin- 2 determines morphine tolerance but not dependence. Nature 408:720-723.

Dang VC, Chieng B, Azriel Y, Christie MJ (2011) Cellular morphine tolerance produced by $\beta$ arrestin-2-dependent impairment of $\mu$-opioid receptor resensitization. J Neurosci 31:7122-7130.

Doll C, Konietzko J, Pöll F, Koch T, Höllt V, Schulz S (2011b) Agonistselective patterns of micro-opioid receptor phosphorylation revealed by phosphosite-specific antibodies. Br J Pharmacol. Advance online publication. Retrieved March 30, 2011. doi:10.1111/j.1476-5381.2011.01382.x.

El Kouhen R, Burd AL, Erickson-Herbrandson LJ, Chang CY, Law PY, Loh HH (2001) Phosphorylation of Ser363, Thr370, and Ser375 residues within the carboxyl tail differentially regulates mu-opioid receptor internalization. J Biol Chem 276:12774-12780.

Grecksch G, Bartzsch K, Widera A, Becker A, Höllt V, Koch T (2006) Development of tolerance and sensitization to different opioid agonists in rats. Psychopharmacology (Berl) 186:177-184.

Hull LC, Llorente J, Gabra BH, Smith FL, Kelly E, Bailey C, Henderson G, Dewey WL (2010) The effect of protein kinase C and G protein-coupled receptor kinase inhibition on tolerance induced by mu-opioid agonists of different efficacy. J Pharmacol Exp Ther 332:1127-1135.

Keith DE, Murray SR, Zaki PA, Chu PC, Lissin DV, Kang L, Evans CJ, von Zastrow M (1996) Morphine activates opioid receptors without causing their rapid internalization. J Biol Chem 271:19021-19024.

Kelly E (2011) The subtleties of micro-opioid receptor phosphorylation. Br J Pharmacol. Advance online publication. Retrieved March 30, 2011. doi:10.1111/j.1476-5381.2011.01387.x.

Koch T, Widera A, Bartzsch K, Schulz S, Brandenburg LO, Wundrack N, Beyer A, Grecksch G, Höllt V (2005) Receptor endocytosis counteracts the development of opioid tolerance. Mol Pharmacol 67:280-287.

Law PY, Hom DS, Loh HH (1983) Opiate receptor down-regulation and desensitization in neuroblastoma X glioma NG108-15 hybrid cells are two separate cellular adaptation processes. Mol Pharmacol 24:413-424.

Lupp A, Richter N, Doll C, Nagel F, Schulz S (2011) UMB-3, a novel rabbit monoclonal antibody, for assessing mu-opioid receptor expression in mouse, rat and human formalin-fixed and paraffin-embedded tissues. Regul Pept 167:9-13.

Martini L, Whistler JL (2007) The role of mu opioid receptor desensitization and endocytosis in morphine tolerance and dependence. Curr Opin Neurobiol 17:556-564.

McPherson J, Rivero G, Baptist M, Llorente J, Al-Sabah S, Krasel C, Dewey WL, Bailey CP, Rosethorne EM, Charlton SJ, Henderson G, Kelly E (2010) mu-opioid receptors: correlation of agonist efficacy for signalling with ability to activate internalization. Mol Pharmacol 78:756-766.

Nestler EJ (1996) Under siege: the brain on opiates. Neuron 16:897-900.

Raehal KM, Bohn LM (2011) The role of beta-arrestin2 in the severity of antinociceptive tolerance and physical dependence induced by different opioid pain therapeutics. Neuropharmacology 60:58-65.

Schulz S, Mayer D, Pfeiffer M, Stumm R, Koch T, Höllt V (2004) Morphine induces terminal micro-opioid receptor desensitization by sustained phosphorylation of serine-375. EMBO J 23:3282-3289.

Terman GW, Jin W, Cheong YP, Lowe J, Caron MG, Lefkowitz RJ, Chavkin C (2004) G-protein receptor kinase 3 (GRK3) influences opioid analgesic tolerance but not opioid withdrawal. Br J Pharmacol 141:55-64.

Werling LL, McMahon PN, Cox BM (1989) Selective changes in mu opioid receptor properties induced by chronic morphine exposure. Proc Natl Acad Sci U S A 86:6393-6397. 